\title{
IS IT CULTURE OR DEMOCRACY? THE IMPACT OF DEMOCRACY AND CULTURE ON HAPPINESS
}

(Accepted 9 August 2006)

\begin{abstract}
We analyze the relation between democracy and perceived subjective well-being while controlling for other relevant determinants such as culture measured by languages. We conduct a cross-national analysis covering 28 countries using data from the 1998 International Social Survey Programme. Contrasting existing empirical evidence, we observe a significant positive relationship between democracy and happiness even when controlling for income and culture measured by language and religion. The effect of democracy on happiness is stronger in countries with an established democratic tradition.
\end{abstract}

KEY WORDS: culture, democracy, happiness, institutions, utility

JEL CLASSIFICATIONS: I31, H10, D02

\section{INTRODUCTION}

A more democratic system is likely to produce political outcomes that are closer to the preferences of the citizens than a system with less democratic elements. ${ }^{1}$ Consequently, ceteris paribus, a greater exposure to democracy can be expected to raise individuals' well-being. Not only does such exposure lead to political results that are acceptable to a large part of a population, but citizens' well-being may also arise from their participation in the political decision-making process and from the perceived extent of

Earlier versions of this paper were presented at the Workshop on Happiness, Economics and Interpersonal Relationships (4/12/2004), the International Conference of Panel Data Users in Switzerland (26/02/2005), the American Public Choice Society Conference (10/03/2005), the Annual Conference of the Swiss Society for Statistics and Economics (17/03/2005), and the European Public Choice Society Conference (3/04/2005). We would like to thank conference participants and particularly Alois Stutzer for helpful comments. We thank the Swiss National Science Foundation for financial support (Grant-No. 5004-58524). 
procedural fairness of this process. In fact, such procedural utility might be even larger than the utility gained from a (democratic) political outcome. ${ }^{2}$

Therefore, we expect empirical research to show that a higher level of democratization of a country leads to a higher level of self-reported happiness. However, the limited empirical evidence from international crosssectional studies only partly supports this proposition. Based on a sample of about 40 nations drawn from the World Values Survey, Schyns (1998) and Veenhoven (2000a) find a positive and significant correlation between the Freedom House Democracy Index and self-reported happiness. However, this correlation becomes insignificant once the different national income levels are controlled for. ${ }^{3}$ In another study based on the World Values Survey, Inglehart and Klingemann (2000) note that "[our] findings undermine any simplistic assumption that democratic institutions are the main determinant of human happiness" (p. 180).

The only scholars who find a positive and robust influence of democracy on subjective life satisfaction are Frey and Stutzer who conducted a series of analyses focused on the particular case of Switzerland. ${ }^{4}$ They exploit the fact that the Swiss federal structure allows for considerable variation in political institutions across the 26 cantons, especially with regard to direct popular rights. One drawback of the Swiss case is, however, that the political rights of Swiss citizens vary only with respect to the cantonal and local levels. At the federal level, citizens from all cantons have the same political rights with regard to such important policy fields as foreign policy, trade, defence, or the social security system. ${ }^{5}$ Hence, measured on an international scale, the extent of democratic rights is very high for all Swiss cantons, but the variation in the degree of democracy (and in other political institutions) between cantons is relatively small. An international sample that includes, for example, established democracies like Great Britain or the United States, as well as relatively weak democracies such as Russia, will clearly yield a much higher variation of democracy levels. It is conceivable that this higher variation in democracy levels in an international setting should also have a more notable impact on self-reported overall happiness.

It can be argued that a cross-national analysis of subjective well-being is difficult because countries vary not only in terms of democracy, but also with regard to other determinants that might influence individual happiness, such as income and culture. Any cross-national empirical analysis must take such factors into account. A particularly important determinant is culture: people in different cultures may value certain aspects of life differently and could, therefore, have different perceptions of their own individual wellbeing under the same objective circumstances. ${ }^{6}$ This possibility is also noted 
by Easterlin (1974, p. 108), and several more recent papers examine this relationship. ${ }^{7}$

The case study of Switzerland highlights the importance of such cultural differences. The country is divided into three major language regions with rather different cultures, with the borderline being mainly between the German-speaking region on the one hand and the French- and Italianspeaking regions on the other hand. In fact, voting patterns in recent public elections reveal substantial differences among the different language regions within Switzerland. ${ }^{8}$ In their happiness analysis, Stutzer and Frey (2003) use the state language as a proxy for the regionally dominating culture, and the coefficients of the language variables are typically highly significant when self-reported well-being is regressed on a commonly used set of determinants of happiness. Moreover, Dorn et al. (2005) find that the impact of cantonal democracy levels on well-being is small and insignificant once cultural variables at the individual and state levels are included in the regression equations. Thus, cultural aspects, which have previously been shown to be a main source of differences in the political behavior in different countries, may also play a major role in determining self-reported happiness. Hence, not only in the Swiss case, but even more in international studies, an analysis of the effects of democracy on happiness must control for culture.

The use of the main language of a country to reflect national culture can be justified because, in society, language serves as an important transmission channel of culture and its embedded view of the world, the social system, and customs. At the individual level, the mother tongue shapes human patterns of thought, a view advocated not only by sociobiologists (e.g., Allott, 1999) but also by economists (e.g., Lazear, 1999). Consequently, such cultural variations may not only be reflected in institutional differences but also in how individuals value the contribution of political institutions to their individual welfare. Among other factors that are closely related to culture and that might have an impact on people's happiness are individuals' religious denominations, as they reflect differing value systems and determine the goals in life. ${ }^{9}$

Besides democracy and culture, the economic situation of a country will also likely affect the well-being of its population. Economists have carefully studied the impact of income on happiness. As earlier papers by Abramowitz (1959) and Easterlin (1974) indicate, income growth may have a positive effect on personal happiness in the short run but not in the long run. ${ }^{10}$ Consequently, in recent decades, the average level of life satisfaction has remained constant in many countries despite considerable economic growth. ${ }^{11}$ Moreover, Easterlin (1974) shows that countries with rather 
different GNP per capita - for example, West Germany and Nigeria, to mention the two most extreme examples - had nearly the same average personal happiness rating (p. 106). ${ }^{12}$ On the other hand, differences in economic status within a country have a clear and consistent impact on personal happiness. ${ }^{13}$ Thus, to adequately control for the impact of income on happiness, it is necessary to distinguish between the income level within a society, and the relative economic position that an individual or family occupies in this society. In the previous research cited above, based on the World Values Survey data, GDP per capita had to be used as a crude proxy for individual income and a distinction between average income level and relative income position was not feasible.

This paper takes a closer look at the relation between democracy and perceived subjective well-being, while also taking into account the impact of culture measured by languages and religion. We conduct a cross-national analysis covering 28 countries, using data from the 1998 International Social Survey Programme (ISSP). An important advantage of the ISSP data is that they allow for the definition of income variables at the individual level. The model and methodology of this paper are presented in the next section, and the following section shows the empirical results. Even after controlling for culture, income and numerous individual socio-demographic characteristics, we observe a positive and significant relationship between democracy and happiness. The last section concludes.

\section{MODEL AND METHODOLOGY}

The effect of democracy on subjective well-being may be identified in a cross-national setting in which sufficient variation in exposure to democracy can be observed. Obviously, as discussed above, such a cross-national analysis requires a rich set of available conditioning variables to control for the multifaceted happiness-influencing differences among individuals and among countries. An appropriate dataset for this purpose is the 1998 ISSP, an ongoing program of cross-national collaboration that started in 1985. The ISSP data are collected by independent institutions in several countries and topics covered by the data change from year to year. One advantage of this international micro dataset is, as already mentioned above, that it includes the interviewee's household income, which otherwise had to be substituted with crude income measures at the aggregate level. ${ }^{14}$

We start with the model developed by Frey and Stutzer (2000) who analyzed well-being using ordered probit and a rich set of socio-demographic and socio-economic control variables. These variables include 
gender, age, education, marital status, household type, and employment status. We deviate from the approach by Frey and Stutzer in two respects. Following the literature mentioned in the introduction, first, we explicitly take into account the potential impact of culture by including control variables for the main language of the country and for the religious denomination of the interviewee. Second, we do not look only at the effect of (absolute) personal income but rather distinguish between the income level within a country on the one hand and the relative income position of the individual on the other. ${ }^{15}$ We eliminate observations with missing values in the control variables.

Two measures of individual happiness are often encountered in the literature. While nearly all authors speak of happiness, only some surveys truly question respondents about their personal happiness; the others ask about personal satisfaction or well-being. This first holds true for the ISSP 1998, while the second type of question was used, e.g., in the Swiss analyses by Frey and Stutzer. However, personal satisfaction on the one hand and happiness on the other may represent quite different aspects of personal life, ${ }^{16}$ particularly (but not exclusively) for speakers of the German language. Nevertheless, the literature usually assumes that these two personal emotions are comparable insofar as they are both highly correlated with themselves and with other explanatory variables. ${ }^{17}$ Therefore, and in accordance with the usual practice, the two terms are used interchangeably in this study.

In the 1998 wave of the ISSP, the survey's first question was as follows:

If you were to consider your life in general these days, how happy or unhappy would you say you are, on the whole?

Respondents could rate themselves as 'very happy,' 'fairly happy,' 'not very happy,' or 'not happy at all.' Table I shows the distribution of these answers in the 28 countries. In all countries but Latvia, more than half the population consider themselves as either 'very happy' or 'fairly happy,' with 'fairly happy' being the most frequent happiness assessment in all but two countries. Nevertheless, some considerable differences between countries can be observed; for example, $44.1 \%$ of the Irish consider themselves 'very happy,' whereas this figure is as low as $4.6 \%$ for Latvia and $4.7 \%$ for Hungary and Russia.

To estimate the model, we use an unweighted ordered probit model with standard errors clustered by countries. The clustering permits that the error terms of individuals living in the same country can be correlated, while the assumption of no correlation is only upheld across countries. For the 
TABLE I

Self-reported happiness in 28 countries (in \%)

\begin{tabular}{lrlrcl}
\hline & $\begin{array}{c}\text { Very } \\
\text { happy }\end{array}$ & $\begin{array}{l}\text { Fairly } \\
\text { happy }\end{array}$ & $\begin{array}{l}\text { Not very } \\
\text { happy }\end{array}$ & $\begin{array}{l}\text { Not at all } \\
\text { happy }\end{array}$ & $\begin{array}{l}\text { Mean } \\
\text { score }\end{array}$ \\
\hline Austria & 22.6 & 67.8 & 8.6 & 0.9 & 3.12 \\
Bulgaria & 8.7 & 45.1 & 28.7 & 17.4 & 2.45 \\
Canada & 25.4 & 57.8 & 14.5 & 2.2 & 3.06 \\
Chile & 27.5 & 32.3 & 34.8 & 5.4 & 2.82 \\
Cyprus & 21.7 & 50.6 & 22.5 & 5.2 & 2.89 \\
Czech Republic & 8.9 & 71.3 & 17.9 & 1.8 & 2.87 \\
Denmark & 31.8 & 57.7 & 8.7 & 1.8 & 3.19 \\
France & 14.1 & 65.1 & 17.8 & 3.0 & 2.90 \\
Germany (West) & 17.7 & 66.2 & 13.5 & 2.6 & 2.99 \\
Germany (East) & 9.3 & 61.2 & 25.3 & 4.2 & 2.76 \\
Hungary & 4.7 & 45.1 & 39.6 & 10.6 & 2.44 \\
Ireland & 44.1 & 50.9 & 4.4 & 0.6 & 3.38 \\
Italy & 12.4 & 65.9 & 18.2 & 3.5 & 2.87 \\
Japan & 14.3 & 74.1 & 10.0 & 1.6 & 3.01 \\
Latvia & 4.6 & 43.9 & 45.0 & 6.5 & 2.47 \\
New Zealand & 33.0 & 59.9 & 6.4 & 0.6 & 3.25 \\
Norway & 22.1 & 66.6 & 10.4 & 0.9 & 3.10 \\
Philippines & 27.8 & 53.3 & 15.0 & 3.9 & 3.05 \\
Poland & 19.0 & 63.0 & 15.3 & 2.7 & 2.98 \\
Portugal & 19.5 & 37.5 & 34.9 & 8.0 & 2.69 \\
Russia & 4.7 & 49.4 & 37.1 & 8.8 & 2.50 \\
Slovak Republic & 7.1 & 58.3 & 26.2 & 8.4 & 2.64 \\
Slovenia & 9.3 & 58.6 & 28.8 & 3.3 & 2.74 \\
Spain & 19.2 & 68.1 & 11.1 & 1.6 & 3.05 \\
Sweden & 24.4 & 61.2 & 12.8 & 1.6 & 3.08 \\
Switzerland & 28.4 & 62.1 & 8.5 & 0.9 & 3.18 \\
United Kingdom & 35.1 & 58.1 & 5.7 & 1.1 & 3.24 \\
United States & 36.7 & 52.4 & 8.9 & 2.0 & 3.24 \\
\hline
\end{tabular}

The mean score is obtained by transforming the ordinal scale to a cardinal scale (score 4 for 'very happy', score 3 for 'fairly happy', score 2 for 'not very happy', score 1 for 'not happy at all').

institutional variables measured at the country level, such as democracy, the degree of freedom is then limited by the number of countries in the sample and not determined by the number of survey respondents (Moulton, 1990). As a robustness test, we also carry out the identical estimation with additional macroeconomic determinants included in the model.

To capture the impact of the political system on self-reported happiness, we use two different measures of democracy: the Polity IV index by Marshall and Jaggers (2003) and the Freedom House index by Karatnycky (2000). The Polity IV index, which is based on a relatively narrow definition 
of democracy, assesses the openness of democratic institutions on a scale from 0 to 10 . Components of the index include the extent to which political executives are chosen through competitive elections and the opportunity of non-elites to access institutional structures for political expression and to attain political office. In contrast, the Freedom House democracy index uses a broader concept of democracy; it measures a wide array of political rights and civil liberties on a 7-point scale. These include basic economic and social freedoms, such as the right to establish a private business or the right of gender equality. Index values are summarized in Table A.I of the Appendix.

Based on each of these indices, two variables are defined: one for the democracy level in 1988, and a second one for the increase in democracy between 1988 and 1998. This structure takes into account that the ISSP includes various transitional countries in which democratic structures have only been established very recently, i.e. between 1988 and $1998{ }^{18}$ It seems plausible to assume that these new democratic structures would not have the same impact on happiness as the structures already established a decade or more ago, i.e. before 1988 .

As is common in such studies, language - which can play an important role at different levels, institutional as well as individual - proxies for culture. To account for culture by language, binary variables are defined for 'English,' 'German,' 'North Germanic' (Scandinavian), 'Romance,' 'BaltoSlavic, Uralic and Greek,' and 'Asian' (Japanese and Filipino) languages. In the regressions, 'English' is used as the reference group. Controlling for culture (i.e. language) at the individual level might be important because the set of factors that contributes to personal satisfaction and the perception of the benefits of democratic institutions may vary with individual cultural background. Unfortunately, in the ISSP 1998 survey, information on the ethnic origin of the respondent is available only for half the countries so that an individual language measure could not be included.

Another possible variable to represent culture is religion. In some countries, ethnic groups (or language groups) correspond with differing religious affiliations, whereas in others, such as Switzerland, religion and language are not highly correlated. The ISSP data allow to control for religious denominations at the individual level. We use a set of dichotomous variables indicating whether an individual categorizes herself as 'Catholic,' 'Anglican,' 'Orthodox,' 'other Christian,' belonging to a 'non-Christian religion' or having 'no religion,' with 'Protestant' forming the reference category.

The equivalence income is computed in U.S. dollars using purchasing power parity data from Penn World Table 6.1 and the modified OECD 
equivalence scale. ${ }^{19}$ Since data on the exact household composition is unavailable, it is assumed that at least one person in each household is an adult, while the remaining household members are equally divided into adults and children. To differentiate between the income level of a country and the relative income positions of individuals, we include subsistence income, defined as $40 \%$ of the average income in the respective country, and the difference between actual individual income and subsistence income. Moreover, to allow for the likely nonlinearity of the income effect, the base model includes the squares of these income differences, calculated separately for positive and negative differences. Assuming a positive but decreasing marginal utility of income, we expect a positive sign for the relative income variable and a negative one for its squared term. If only relative income matters, the coefficient of subsistence income should be zero. If only absolute income matters, the coefficients of subsistence and relative income should be both positive and identical.

\section{EMPIRICAL RESULTS}

Following the Hendry approach, we start with the comprehensive model estimated separately for both democracy indices. The results are given in Table A.II of the Appendix. In both cases, the squared income variable for those below the poverty line does not prove significant. Therefore, this variable is excluded for further analysis. The subsequent discussion of the results is restricted to the reduced model of the ISSP dataset.

The results for the democracy, income and language variables are given in Table II. Established democratic structures as represented by the Polity IV democracy index for the year 1988 have a positive impact on happiness which is statistically significant at the $5 \%$ level. Given that only 28 countries pertain to the sample, which causes the degrees of freedom for variables measured at the country level to be small, we consider this significance level to be quite high. The effect of democracy can be observed even though many relevant sociodemographic and economic factors, including individual household income, have been controlled for. This finding is robust with respect to the inclusion of language and religious denomination variables. If the Freedom House democracy index is used in place of the Polity IV measure, the coefficient of the democracy 1988 variable is even larger, although its statistical significance level is slightly lower. The marginal effect of democracy on happiness is sizable: one additional point on the Freedom House scale increases the probability that a subsistence income earner is 'very happy' by as much as an increase of the equivalence income by 7,000 


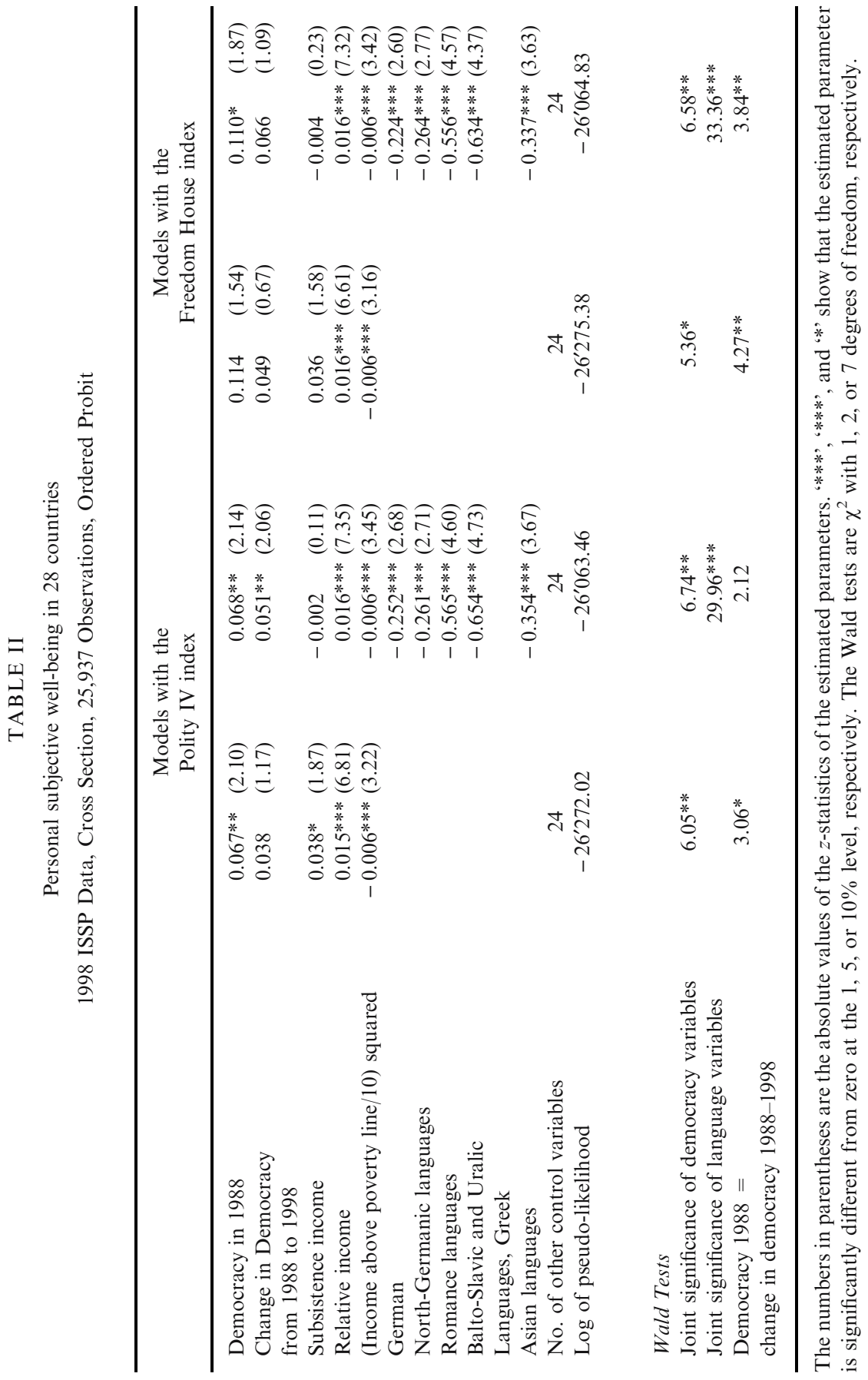


U.S. dollars per year. ${ }^{20}$ These results strongly support the hypothesis that a higher degree of democracy in a country increases citizens' happiness.

Democratic structures that were newly acquired between 1988 and 1998 have a positive, but in most specifications insignificant impact on happiness. The Wald tests show that in three of the four estimations, the newly established democratic structures have a significantly weaker positive effect on happiness than the older democratic institutions that were already in place in $1988 .{ }^{21}$ Between 1988 and 1998, several countries in the sample predominantly in Eastern Europe - went through a transition from authoritarian regimes to democratic systems. These estimation results are consistent with the notion that residents of these countries do not (yet) benefit as much from democracy as do residents of countries with longer democratic traditions. The reason may be that democratic institutions have not been in place long enough to permit substantial change toward more broadly accepted policies. Moreover, it has been observed in transitioning countries that the introduction of democracy may create overly optimistic expectations with regard to the future that later may not be fulfilled, thus resulting in decreasing happiness during at least a part of the transition process. $^{22}$

Culture, as measured by the language variables, has a very strong impact on subjective well-being. Ceteris paribus, residents of predominantly English-speaking countries report higher levels of life satisfaction than residents from countries with other cultures. ${ }^{23}$ Conversely, levels of self-reported happiness tend to be lowest in countries outside the Germanic language tradition, i.e. where neither English, German, nor North-Germanic (Scandinavian) languages are spoken. In countries with a Balto-Slavic, Uralic, or Greek language, the predicted probability that a survey respondent be 'very happy' is ceteris paribus more than 16 percentage points lower than in a country where English is spoken. ${ }^{24}$ These results support our hypothesis that culture plays an important role in determining well-being. While we do not claim to having identified the cause of culture's impact, several explanations seem consistent with these findings. First, in some cultures, there may be a social expectation that individuals should answer questions about their well-being by saying that they were 'happy' or 'very happy,' while such a positive assessment is not necessarily a social norm in other cultures. Moreover, it is possible that the pursuit of happiness might not be of equal importance as a goal of life in every culture. ${ }^{25}$ Finally, given that the term 'happiness' might not have the exactly identical meaning across languages, such language differences might contribute to differences in the levels of selfreported well-being. 
With respect to religious denominations, which arguably also capture cultural identity, the results show on the one hand that there are no significant differences between various Christian denominations. On the other hand, individuals with a 'non-Christian religion' and with 'no religious denomination' report significantly lower happiness levels than the reference group. ${ }^{26}$ The distinction between national income level and relative income position of individuals proves to be relevant. Relative income is always highly significant, while subsistence income is usually insignificant. This finding provides evidence in favor of the relative income hypothesis. Moreover, the squared income above the poverty line is always highly significantly negative, indicating decreasing marginal utility of income.

We tested the robustness of democracy's effect on well-being using the baseline model (as reported in columns two and four of Table II) by controlling for several variables that capture important aspects of the general economic conditions of a country; namely growth of real GDP per capita, unemployment, and consumer price inflation. ${ }^{27}$ The results of the robustness tests are reported in Table III. The additional macro-level variables which were added one by one or jointly to the baseline model all have clearly insignificant coefficients. The democracy variables remain significant when controlling for the unemployment rate. The inclusion of inflation or GDP growth, however, strongly inflates standard errors such that the democracy variables are no longer significant. ${ }^{28}$ Nonetheless, throughout all the additional specifications, the coefficients of the democracy variables remain roughly at the level of the baseline model. Furthermore, given the insignificance of the control variables, a general-to-specific analysis would again lead back to the baseline model presented in Table II and in the first column of Table III.

In conclusion, we find a significant impact of the degree of democratization on people's self-reported happiness, even if we control for culture as represented by national language and individual religion. Furthermore, the robustness tests suggest that macro-economic conditions only partly serve as channels of transmission but that a direct institutional linkage persists beyond. ${ }^{29}$ With this finding, we contradict extant empirical analyses using cross-national individual data which found the influence of national income to be dominating over political institutions (e.g. Schyns, 1998; Veenhoven, 2000a). In light of this previous research, our results also reveal the importance of data quality and the insubstitutability of missing individual income data with aggregate GDP per capita. In addition, we contrast the recent findings for Switzerland in Dorn et al. (2005) which revealed no association of participatory rights with self-reported well-being once cultural influences were taken into account. 


\section{TABLE III}

Robustness tests

1998 ISSP Data, Cross Section, 25,937 Observations, Ordered Probit

\begin{tabular}{|c|c|c|c|c|c|}
\hline \multirow[b]{2}{*}{ Democracy in 1988} & \multirow[b]{2}{*}{$\begin{array}{l}0.068^{* *} \\
(2.14)\end{array}$} & \multirow[b]{2}{*}{$\begin{array}{l}0.076^{* * *} \\
(3.12)\end{array}$} & \multicolumn{3}{|c|}{$\begin{array}{l}\text { Models with the Polity IV } \\
\text { Index }\end{array}$} \\
\hline & & & $\begin{array}{l}0.079 \\
(1.24)\end{array}$ & $\begin{array}{l}0.052 \\
(1.10)\end{array}$ & $\begin{array}{l}0.083 \\
(1.30)\end{array}$ \\
\hline Change in Democracy & $0.051^{* *}$ & $0.060 * *$ & 0.062 & 0.037 & 0.070 \\
\hline 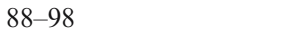 & $(2.06)$ & $(2.47)$ & $(1.00)$ & $(0.81)$ & (1.09) \\
\hline Unemployment rate & & $\begin{array}{l}0.009 \\
(0.72)\end{array}$ & & & $\begin{array}{l}0.009 \\
(0.85)\end{array}$ \\
\hline Inflation & & & $\begin{array}{l}0.003 \\
(0.26)\end{array}$ & & $\begin{array}{l}0.011 \\
(0.65)\end{array}$ \\
\hline $\begin{array}{l}\text { Growth rate of real } \\
\text { GDP p.c. }\end{array}$ & & & & $\begin{array}{l}0.014 \\
(0.58)\end{array}$ & $\begin{array}{l}0.026 \\
(0.78)\end{array}$ \\
\hline \multirow{4}{*}{$\begin{array}{l}\text { Wald Tests } \\
\text { Joint significance } \\
\text { of democracy variables } \\
\text { Joint significance } \\
\text { of control variables }\end{array}$} & & & & & \\
\hline & $6.74 * *$ & $10.08 * * *$ & 3.06 & 2.31 & 2.70 \\
\hline & & & & & 1.22 \\
\hline & & & \multicolumn{3}{|c|}{$\begin{array}{c}\text { Models with the Freedom } \\
\text { House index }\end{array}$} \\
\hline Democracy in 1988 & $\begin{array}{l}0.110^{*} \\
(1.87)\end{array}$ & $\begin{array}{l}0.130^{* *} \\
(2.08)\end{array}$ & $\begin{array}{l}0.111 \\
(0.78)\end{array}$ & $\begin{array}{l}0.076 \\
(0.84)\end{array}$ & $\begin{array}{l}0.145 \\
(1.05)\end{array}$ \\
\hline Change in Democracy & 0.066 & 0.083 & 0.067 & 0.036 & 0.113 \\
\hline 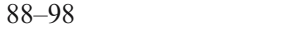 & (1.09) & $(1.33)$ & $(0.47)$ & $(0.38)$ & $(0.76)$ \\
\hline Unemployment rate & & $\begin{array}{l}0.009 \\
(0.69)\end{array}$ & & & $\begin{array}{l}0.011 \\
(0.83)\end{array}$ \\
\hline Inflation & & & $\begin{array}{l}0.001 \\
(0.06)\end{array}$ & & $\begin{array}{l}0.010 \\
(0.47)\end{array}$ \\
\hline Growth rate of real & & & & 0.015 & 0.024 \\
\hline GDP p.c. & & & & $(0.62)$ & $(0.69)$ \\
\hline Wald Tests & & & & & \\
\hline $\begin{array}{l}\text { Joint significance } \\
\text { of democracy variables }\end{array}$ & $6.58 * *$ & $6.90^{* *}$ & $5.18^{*}$ & $4.65^{*}$ & 4.57 \\
\hline $\begin{array}{l}\text { Joint significance } \\
\text { of control variables }\end{array}$ & & & & & 0.96 \\
\hline
\end{tabular}

Absolute values of $z$-statistics in parentheses, '***', '**', and '*' indicate that the estimated paramater is significantly different from zero at the 1,5 , or $10 \%$ level, respectively. The Wald tests are $\chi^{2}$ with 2 and 3 degrees of freedom. 


\section{SUMMARY AND CONCLUDING REMARKS}

In this paper, we analyze the impact of democracy on subjective well-being in an international comparison of 28 countries. We control not only for a multitude of sociodemographic and economic determinants of life satisfaction, but also for cultural influences as captured by language and religion variables.

Contrasting earlier empirical evidence (e.g. Schyns, 1998; Veenhoven, 2000a), our analysis is the first study that reports a significant influence of democracy on individuals' subjective well-being in an international context. The result is robust to the inclusion of culture and income variables. Furthermore, the effect of democracy remained positive when macro-economic variables were added to the model. These findings provide empirical support for theoretical work in the field of political economy which suggests that higher levels of democracy will, ceteris paribus, lead to procedures and policies that correspond more closely to voters' preferences and thus increase people's happiness.

In our investigation, culture as measured by language has a considerable impact on subjective well-being while religious denomination is less decisive. The impact of language is also more robust than the effect of political institutions. With regard to national culture, it appears that the happiest people live in English-speaking nations, followed by individuals in Germanspeaking and Scandinavian nations.

Finally, we confirm previous research by showing that relative income has a positive impact on happiness, but with diminishing returns. This result is consistent with the usual assumption of decreasing marginal utility. Whether the absolute income of a person also has an impact on happiness is not unambiguously determined by this study. However, even if absolute income has an additional impact on happiness, the effect of relative income clearly dominates.

The question of whether or not democracy increases happiness is especially timely in view of the transitioning of many countries from authoritarian to democratic structures within the past 20 years. Our results show that, compared to countries with a longer democratic tradition, the positive effect of democracy on life satisfaction is smaller in these transitioning countries. Thus, after the introduction of democratic structures, it may take some time before the full benefits of democracy in the form of higher individual life satisfaction can be reaped. 


\section{NOTES}

${ }^{1}$ See, e.g., Pommerehne (1978) or, for theoretical models, Besley and Coate (2001) or Feld and Kirchgässner (2001).

${ }^{2}$ See Stutzer and Frey (2003) and Frey and Stutzer (2005).

${ }^{3}$ See also Bjørnskov (2003) for a similar result.

${ }^{4}$ See, e.g., Frey and Stutzer (2000, 2002), as well as Stutzer and Frey (2003). In an international context, Jungeilges and Kirchgässner (2002) found a negative relation between the extent of civil liberties and suicide rates.

5 Among the important fields of politics at the cantonal level are education, welfare, and police.

${ }^{6}$ For this, see, e.g., Lijphart (1979), or the difference between Europeans and Americans with respect to (economic) inequality shown in Alesina et al. (2004).

7 See, e.g., the contributions in Diener and Suh (2000). For the effect of culture on economic outcomes see, e.g., Guiso et al. (2006).

${ }^{8}$ See also Lijphart (1979), who concluded that "because language is a crucial differentiator among nations, it is bound to be a major cleavage and a main source of partisan differences in 'nations' that are not linguistically homogeneous" (p .453).

${ }^{9}$ See, e.g., Ferriss (2002) or Bjørnskov (2003).

${ }^{10}$ As soon as individuals adjust to their new situation, the level of happiness may settle down to the old equilibrium. See, e.g., Easterlin (2001, 2003).

${ }^{11}$ Several studies provide evidence for this observation. See, e.g., the papers cited in Frey and Stutzer (2002, p. 413), and also Frank (1997), Oswald (1997), McBride (2001), and Easterlin (2003). The long-term impact may even go in the reverse direction, from happiness to economic growth. See for this Kenny (1999).

${ }_{12}$ See also the graph in Frey and Stutzer (2002, p. 417), which suggests that above a level of about 5,000 US dollars per capita (in 1995 PPP) there exists no obvious relation between GNP per capita and personal happiness (see also Bjørnskov et al., 2005). That absolute income might, nevertheless, also have an impact on happiness is shown, e.g., by Schyns (2002).

${ }^{13}$ For the impact of relative income on happiness see, e.g., D'Ambrosio and Frick (2004), Luttmer (2004) as well as DiTella and MacCulloch (2005). Another question is whether it is really income and not wealth together with income that matters. For this, see Headey and Wooden (2004) or Headey et al. (2004).

${ }^{14}$ In contrast, the World Value Survey data contain household income information in form of income brackets.

${ }^{15}$ The variables used in the model are listed in Table A.III of the Appendix. Minor differences in the model specification are caused by the availability of explanatory variables.

${ }^{16}$ For the difference between satisfaction and happiness see, e.g., Lane (1991, chapter 22) or Veenhoven (2000b).

${ }^{17}$ See, e.g. Veenhoven (2000a).

${ }^{18}$ It should be noted that the sample includes no country in which the Polity IV democracy level decreased between 1988 and 1998. In the same period, the Freedom House democracy score slightly declined in three countries of the sample. The variable 'Increase in Freedom House Democracy Score 1988-1998' assumes a negative value for these countries.

19 See Heston et al. (2002) and Van Doorslaer and Masseria (2004, p. 12).

${ }^{20}$ In the model that includes controls for languages and religion, the marginal effects for being 'very happy' are 0.0279 for the Freedom House democracy level 1988, 0.0040 for relative income measured in \$K, and minus 0.0017 for (relative income/10) squared. One additional point on the Polity index scale has the same effect as an additional income of $\$ 4,500$. The full list of marginal effects can be obtained from the authors. 
${ }^{21}$ Note that in every model of Table I additional Wald tests consistently reject the null hypothesis that the coefficients of the two democracy variables are jointly equal to zero at least at the $10 \%$ level.

22 See Moller and Dickow (2002) for South Africa, or Veenhoven (2001) for Russia. Note that the cross-section data of the ISSP does not allow to specifically model such transition processes. ${ }^{23}$ One reader of this paper suggested that English-speaking countries are more affected by migration than others, which would cause an upward bias to well-being if migrants were particularly happy. However, when we analyze a country-specific variable for ethnic origin in the subsample of residents of the United Kingdom, we find no evidence that would support this claim. 24 The marginal effects of the language variables on the probability of being 'very happy' are (in comparison to English) -0.064 for German, -0.066 for North-Germanic languages, -0.143 for Romance languages, -0.166 for Balto-Slavic, Uralic, and Greek languages, and -0.090 for Asian languages. The reported values refer to the model that uses the Polity IV democracy index; however, almost identical marginal effects are obtained with the Freedom House index. ${ }^{25}$ For this, see, e.g., Ahuvia (2002).

${ }^{26}$ See the results in Table A.II of the Appendix. Similarly, Ferriss (2002) finds for the US that differences in happiness between the main denominations of Judeo-Christianism appear negligible.

${ }^{27}$ Definitions and sources of these variables are given in Table A.III of the Appendix. Note that the income level of a country is already controlled for by the substitution income variable, which is here defined as $40 \%$ of a country's average income level.

${ }^{28}$ In the models using the Freedom House index, Wald tests always reject the null hypothesis that both democracy variables have zero impact on happiness at least close to the $10 \%$ level. With the Polity index, the results are somewhat weaker.

${ }^{29}$ In the Swiss context, for the impact of democracy on economic performance see Feld and Savioz (1997), or in a cross-national context, Barro (1996) and Perotti (1996). On inflation, see Desai et al. (2003).

\section{APPENDIX}

TABLE A.I

Democracy index levels in 28 countries

\begin{tabular}{|c|c|c|c|c|}
\hline & \multicolumn{2}{|c|}{ Polity IV index } & \multicolumn{2}{|c|}{ Freedom House index } \\
\hline & 1988 & $\begin{array}{l}\text { Change } \\
1988-1998\end{array}$ & 1988 & $\begin{array}{l}\text { Change } \\
1988-1998\end{array}$ \\
\hline Austria & 10.0 & 0.0 & 7.0 & 0.0 \\
\hline Bulgaria & 0.0 & 8.0 & 1.0 & 4.5 \\
\hline Canada & 10.0 & 0.0 & 7.0 & 0.0 \\
\hline Chile & 2.0 & 6.0 & 3.5 & 2.0 \\
\hline Cyprus & 10.0 & 0.0 & 6.5 & 0.5 \\
\hline Czech Republic & 0.0 & 10.0 & 1.5 & 5.0 \\
\hline Denmark & 10.0 & 0.0 & 7.0 & 0.0 \\
\hline France & 9.0 & 0.0 & 6.5 & 0.0 \\
\hline Germany (West) & 10.0 & 0.0 & 6.5 & 0.0 \\
\hline Germany (East) & 0.0 & 10.0 & 1.5 & 5.0 \\
\hline Hungary & 2.0 & 8.0 & 3.5 & 3.0 \\
\hline
\end{tabular}


TABLE A.I

Continued

\begin{tabular}{|c|c|c|c|c|}
\hline & \multicolumn{2}{|c|}{ Polity IV index } & \multicolumn{2}{|c|}{ Freedom House index } \\
\hline & 1988 & $\begin{array}{l}\text { Change } \\
1988-1998\end{array}$ & 1988 & $\begin{array}{l}\text { Change } \\
1988-1998\end{array}$ \\
\hline Ireland & 10.0 & 0.0 & 7.0 & 0.0 \\
\hline Italy & 10.0 & 0.0 & 7.0 & -0.5 \\
\hline Japan & 10.0 & 0.0 & 7.0 & -0.5 \\
\hline Latvia & 0.0 & 8.0 & 2.5 & 4.0 \\
\hline New Zealand & 10.0 & 0.0 & 7.0 & 0.0 \\
\hline Norway & 10.0 & 0.0 & 7.0 & 0.0 \\
\hline Philippines & 8.0 & 0.0 & 5.5 & 0.0 \\
\hline Poland & 0.0 & 9.0 & 3.0 & 3.5 \\
\hline Portugal & 10.0 & 0.0 & 6.5 & 0.5 \\
\hline Russia & 0.0 & 4.0 & 2.5 & 1.5 \\
\hline Slovak Republic & 0.0 & 9.0 & 1.5 & 4.5 \\
\hline Slovenia & 1.0 & 9.0 & 3.0 & 3.5 \\
\hline Spain & 10.0 & 0.0 & 6.5 & 0.0 \\
\hline Sweden & 10.0 & 0.0 & 7.0 & 0.0 \\
\hline Switzerland & 10.0 & 0.0 & 7.0 & 0.0 \\
\hline United Kingdom & 10.0 & 0.0 & 7.0 & -0.5 \\
\hline United States & 10.0 & 0.0 & 7.0 & 0.0 \\
\hline
\end{tabular}

The Polity IV democracy index is measured on a 10-point scale and the Freedom House index is measured on a 7-point scale. In the case of both indices, higher scores represent higher levels of democracy.

TABLE A.II

Results comprehensive model

\begin{tabular}{|c|c|c|}
\hline & $\begin{array}{l}\text { Model with the } \\
\text { Polity IV index }\end{array}$ & $\begin{array}{l}\text { Model with the } \\
\text { Freedom House index }\end{array}$ \\
\hline Democracy in 1988 & $0.068 * * \quad(2.54)$ & $0.110^{*}$ \\
\hline $\begin{array}{l}\text { Change in democracy } \\
\text { from } 1988 \text { to } 1998\end{array}$ & $0.051 * * \quad(2.06)$ & $(1.09)$ \\
\hline Age $<30$ & Reference category & \\
\hline Age $30-39$ & $-0.096 * * \quad(2.46)$ & $-0.096 * * \quad(2.43)$ \\
\hline Age $40-49$ & $-0.216 * * *(5.30)$ & $-0.214 * * *(5.29)$ \\
\hline Age $50-59$ & $-0.233 * * *(4.58)$ & $-0.232 * * *(4.51)$ \\
\hline Age $60-69$ & $-0.131 * * \quad(2.15)$ & $-0.127^{* *}(1.40)$ \\
\hline Age $70-79$ & $-0.087 \quad(1.43)$ & $-0.085 \quad(1.40)$ \\
\hline Age 80 and older & $(1.35)$ & (1.39) \\
\hline
\end{tabular}


TABLE A.II

Continued

\begin{tabular}{|c|c|c|}
\hline & $\begin{array}{l}\text { Model with the } \\
\text { Polity IV index }\end{array}$ & $\begin{array}{l}\text { Model with the } \\
\text { Freedom House index }\end{array}$ \\
\hline Male & Reference category & \\
\hline Female & $0.018 \quad(1.00)$ & $(0.99)$ \\
\hline Low education & Reference category & \\
\hline Middle education & $0.106^{* * *}(3.60)$ & $0.094 * * *(2.80)$ \\
\hline High education & $0.147 * * *(4.20)$ & $0.134 * * *(3.48)$ \\
\hline Single & $0.038 \quad(1.03)$ & $0.054 \quad(1.41)$ \\
\hline Married / living together & Reference category & \\
\hline Divorced or separated & $-0.334 * * *(9.76)$ & $-0.338 * * *(10.22)$ \\
\hline Widowed & $-0.318^{* * *}(7.87)$ & $-0.321^{* * *}(7.74)$ \\
\hline Household with one person & $-0.277 * * *(5.45)$ & $-0.289 * * *(5.80)$ \\
\hline Household with two persons & Reference category & \\
\hline $\begin{array}{l}\text { Household with more } \\
\text { than two persons }\end{array}$ & $0.142 * * *(6.16)$ & $0.142 * * *(6.06)$ \\
\hline Employed & Reference category & \\
\hline Self-employed & $0.063^{* *}(2.34)$ & $0.061^{* *}(2.24)$ \\
\hline Unemployed & $-0.351 * * *(6.47)$ & $-0.342 * * *(6.27)$ \\
\hline Housewife / houseman & $0.087 * * *(2.62)$ & $0.086^{* *} \quad(2.58)$ \\
\hline Other employment status & $0.034 \quad(1.12)$ & $-0.032 \quad(1.12)$ \\
\hline Subsistence income & $-0.003 \quad(0.15)$ & -0.005 \\
\hline Relative income & $0.016^{* * *}(7.09)$ & $0.016^{* * *}(6.98)$ \\
\hline (Income above poverty line/10) squared & $-0.007 * * *(3.46)$ & $-0.067 * * *(3.43)$ \\
\hline (Income below poverty line/10) squared & $0.116 \quad(0.84)$ & $0.111 \quad(0.77)$ \\
\hline English & Reference category & \\
\hline German & $-0.250 * * *(2.66)$ & $-0.222 * * *(2.58)$ \\
\hline North-Germanic languages & $-0.258 * * *(2.67)$ & $-0.261 * * *(2.73)$ \\
\hline Romance languages & $-0.564 * * *(4.56)$ & $-0.556^{* * *}(4.54)$ \\
\hline Balto-Slavic and Uralic languages, Greek & $-0.653 * * *(4.71)$ & $-0.633 * * *(4.35)$ \\
\hline Asian languages & $-0.353^{* * *}(3.63)$ & $-0.336^{* * *}(3.59)$ \\
\hline Protestant & Reference category & \\
\hline Catholic & $-0.004 \quad(0.06)$ & -0.003 \\
\hline Anglican & -0.001 & $(0.08)$ \\
\hline Orthodox & -0.120 & -0.130 \\
\hline Other Christian church & -0.122 & -0.131 \\
\hline Non-Christian religion & $-0.182^{* * *}(2.68)$ & $-0.176^{* * *}(2.70)$ \\
\hline No religion & $-0.199 * * *(3.94)$ & $-0.193 * * *(3.84)$ \\
\hline Number of observations & 25,937 & 25,937 \\
\hline Log of pseudo-likelihood & $-26,063.01$ & $-26,064.48$ \\
\hline Adjusted McFadden's $R^{2}$ & 0.079 & 0.079 \\
\hline
\end{tabular}

The numbers in parentheses are the absolute values of the $z$-statistics of the estimated parameters. '***, '**, ' '*' show that the estimated parameter is significantly different from zero at the 1,5 , or $10 \%$ level, respectively. 
TABLE A.III

Definition of variables

\begin{tabular}{|c|c|}
\hline Variable & Definition \\
\hline Happiness & Four categories \\
\hline Age $30-39$ & 1 if age is between 30 and 39,0 otherwise \\
\hline Age $40-49$ & 1 if age is between 40 and 49,0 otherwise \\
\hline Age $50-59$ & 1 if age is between 50 and 59,0 otherwise \\
\hline Age $60-69$ & 1 if age is between 60 and 69,0 otherwise \\
\hline Age $70-79$ & 1 if age is between 70 and 79,0 otherwise \\
\hline Age 80 and older & 1 if age is older than 80,0 otherwise \\
\hline Female & 1 if person is female, 0 otherwise \\
\hline Intermediate education & $\begin{array}{l}1 \text { if person has incomplete or completed } \\
\text { secondary II education, } 0 \text { otherwise }\end{array}$ \\
\hline High education & $\begin{array}{l}1 \text { if person has incomplete or completed } \\
\text { tertiary education, } 0 \text { otherwise }\end{array}$ \\
\hline Single & 1 if marital status is single, 0 otherwise \\
\hline Widowed & 1 if marital status is widowed, 0 otherwise \\
\hline Divorced or separated & $\begin{array}{l}1 \text { if marital status is divorced or separated, } \\
0 \text { otherwise }\end{array}$ \\
\hline Household size one person & $\begin{array}{l}1 \text { if person is living in a one-person household, } \\
0 \text { otherwise }\end{array}$ \\
\hline $\begin{array}{l}\text { Household size three or } \\
\text { more persons }\end{array}$ & $\begin{array}{l}1 \text { if person is living in a household with three or } \\
\text { more persons, } 0 \text { otherwise }\end{array}$ \\
\hline Self-employed & $\begin{array}{l}1 \text { if a person is self-employed or employed } \\
\text { in her own company, } 0 \text { otherwise }\end{array}$ \\
\hline Housewife & 1 if person is a housewife or a houseman, 0 otherwise \\
\hline Other employment status & $\begin{array}{l}1 \text { if person works in a family business, } \\
\text { is an apprentice or a student, does military service, } \\
\text { is retired or has a not classified status }\end{array}$ \\
\hline Unemployed & $\begin{array}{l}1 \text { if person is unemployed and either } \\
\text { officially recorded or not, } 0 \text { otherwise }\end{array}$ \\
\hline Subsistence income & $\begin{array}{l}40 \% \text { of the national average equivalence income, } \\
\text { measured in units of } 1000 \text { Dollars per year } \\
\text { (PPP adjusted). Source: Heston et al. (2002). }\end{array}$ \\
\hline Relative income & $\begin{array}{l}\text { Individual deviance from national subsistence } \\
\text { income, measured in units of } 1000 \text { Dollars per year } \\
\text { (PPP adjusted) }\end{array}$ \\
\hline (Income above poverty & Relative income divided by 10 , squared \\
\hline line/10) squared & (if relative income has a positive value) \\
\hline (Income below poverty & Relative income divided by 10 , squared \\
\hline line/10) squared & (if relative income has a negative value) \\
\hline German & 1 if main language of country is German, 0 otherwise \\
\hline North-Germanic languages & $\begin{array}{l}1 \text { if main language of country is a North-Germanic } \\
\text { (Scandinavian) language, } 0 \text { otherwise }\end{array}$ \\
\hline Romance languages & $\begin{array}{l}1 \text { if main language of country is a } \\
\text { Romance language, } 0 \text { otherwise }\end{array}$ \\
\hline $\begin{array}{l}\text { Balto-Slavic, Uralic, } \\
\text { Greek languages }\end{array}$ & $\begin{array}{l}1 \text { if main language of country is Balto-Slavic, } \\
\text { Uralic or Greek language, } 0 \text { otherwise }\end{array}$ \\
\hline
\end{tabular}


TABLE A.III

Continued

\begin{tabular}{|c|c|}
\hline Variable & Definition \\
\hline Asian languages & $\begin{array}{l}1 \text { if main language of country is an Asian language, } \\
0 \text { otherwise }\end{array}$ \\
\hline Catholic & 1 if a person is a Catholic, 0 otherwise \\
\hline Anglican & 1 if a person is an Anglican, 0 otherwise \\
\hline Orthodox & 1 if a person is an Orthodox Christian, 0 otherwise \\
\hline Other Christian church & $\begin{array}{l}1 \text { if a person is associated with Christian church } \\
\text { other than Protestant, Catholic, Anglican, } \\
\text { or Orthodox, } 0 \text { otherwise }\end{array}$ \\
\hline Non-Christian religion & 1 if a person has a non-Christian religion, 0 otherwise \\
\hline No religion & 1 if a person has no religion, 0 otherwise \\
\hline Polity IV democracy index 1998 & $\begin{array}{l}\text { Polity IV democracy index on a scale from } 0 \text { (lowest } \\
\text { level of democracy) to } 10 \text { (highest level } \\
\text { of democracy) }\end{array}$ \\
\hline $\begin{array}{l}\text { Increase in Polity IV democracy } \\
\text { index 1988-1998 }\end{array}$ & $\begin{array}{l}\text { Polity IV democracy score } 1998 \text { minus Polity IV } \\
\text { democracy score 1988. Source: Marshall } \\
\text { and Jaggers (2003). }\end{array}$ \\
\hline $\begin{array}{l}\text { Freedom House democracy } \\
\text { index } 1998\end{array}$ & $\begin{array}{l}\text { Freedom House democracy index on a scale } \\
\text { from } 0 \text { (lowest level of democracy) } \\
\text { to } 7 \text { (highest level of democracy) }\end{array}$ \\
\hline $\begin{array}{l}\text { Increase in Fr. House democracy } \\
\text { index 1988-1998 }\end{array}$ & $\begin{array}{l}\text { Freedom House democracy score } 1998 \text { minus } \\
\text { Freedom House democracy score } 1988 . \\
\text { Source: Karatnycky (2000). }\end{array}$ \\
\hline Unemployment rate & $\begin{array}{l}\text { Unemployment rate } 1998 \text { in \%. Source: } \\
\text { International Labor Organization (2006). }\end{array}$ \\
\hline Inflation & $\begin{array}{l}\text { Consumer price inflation } 1998 \text { in \%. Source: } \\
\text { International Monetary Fund (2005). }\end{array}$ \\
\hline Real GDP p.c. & $\begin{array}{l}\text { Real GDP per capita } 1998 \text { in USD } 1000 . \\
\text { Source: Heston et al. (2002). }\end{array}$ \\
\hline Growth rate of real GDP p.c. & $\begin{array}{l}\text { Growth rate of real GDP per capita } \\
1998 \text { in \%. Source: Heston et al. (2002). }\end{array}$ \\
\hline
\end{tabular}

\section{REFERENCES}

Abramowitz, M.: 1959, 'The welfare interpretation of secular trends in national income and product', in M. Abramowitz et al. (ed.), The Allocation of Economic Resources: Essays in Honor of Bernard Francis Haley (Stanford University Press, Stanford), pp. 1-22.

Ahuvia, A.C.: 2002, 'Individualism/collectivism and cultures of happiness: A theoretical conjuncture on the relationship between consumption, culture and subjective well-being at the national level'. Journal of Happiness Studies 3, pp. 23-36.

Alesina, A., R. Di Tella and R. MacCulloch: 2004, 'Inequality and happiness: Are Europeans and Americans different?'. Journal of Public Economics 88, pp. 2009-2042.

Allott, R.: 1999, 'Evolution and culture: the missing link', in J.M.G. van der Dennen, D. Smillie and D.R. Wilson (eds.), The Darwinian Heritage and Sociobiology (Praeger, Westport), pp. $67-81$. 
Barro, R.J.: 1996, 'Democracy and growth'. Journal of Economic Growth 1, pp. 1-27.

Besley, T. and S. Coate: 2001, 'Lobbying and welfare in a representative democracy'. Review of Economic Studies 58, pp. 67-82.

Bjørnskov, Ch.: 2003, 'The happy few: cross-country evidence on social capital and life satisfaction'. Kyklos 56, pp. 3-16.

Bjørnskov, Ch., A. Dreher and J.A.V. Fischer: 2005, 'Cross-country determinants of life satisfaction: exploring different determinants across groups in society', University of St. Gallen Department of Economics working paper series 2005-19.

D'Ambrosio, C. and J. Frick: 2004, 'Subjective well-being and relative deprivation: An empirical link', Institute for the Study of Labor, Discussion Paper No. 1351.

Desai, R.M., A. Olofsgård and T.M. Yousef: 2003, 'Democracy, inequality, and inflation'. American Political Science Review 97, pp. 391-406.

Diener, E. and E.M. Suh (eds.): 2000, Culture and Subjective Well-Being (MIT Press, Cambridge/London).

DiTella, R. and R. MacCulloch: 2005, 'Gross national happiness as an answer to the Easterlin paradox?', Mimeo, Harvard Business School.

Dorn, D., J.A.V. Fischer, G. Kirchgässner and A. Sousa-Poza: 2005, 'Is it culture or democracy? The impact of democracy, income, and culture on happiness', University of St. Gallen Department of Economics working paper series 2005-12.

Easterlin, R.A.: 1974, 'Does economic growth improve the human lot? Some empirical evidence', in P.A. David and M.W. Reder (eds.), Nations and Households in Economic Growth (Academic Press, New York/London), pp. 89-125.

Easterlin, R.A.: 2001, 'Income and happiness: towards a unified theory'. Economic Journal 111, pp. $465-484$.

Easterlin, R.A.: 2003, 'Building a better theory of well-being', Institute for the Study of Labor, Discussion Paper No. 742, Bonn, March.

Feld, L.P., J.A.V. Fischer and G. Kirchgässner: 2004, 'The effect of direct democracy on income redistribution: Evidence for Switzerland', Paper presented at the Meeting of the American Public Choice Society, Baltimore, March 13, 2004.

Feld, L.P. and G. Kirchgässner: 2001, 'The political economy of direct legislation: Direct democracy in local and regional decision-making'. Economic Policy 33, pp. 329-367.

Feld, L.P. and M.R. Savioz: 1997, 'Direct democracy matters for economic performance: An empirical investigation'. Kyklos 50, pp. 507-538.

Ferriss, A.L.: 2002, 'Religion and the quality of life'. Journal of Happiness Studies 3, pp. 199-215.

Frank, R.H.: 1997, 'The frame of reference as a public good'. The Economic Journal 107, pp. $1832-1847$.

Frey, B.S. and A. Stutzer: 2000, 'Happiness, economy and institutions'. The Economic Journal 110 , pp. 918-938.

Frey, B.S. and A. Stutzer: 2002, 'What can economists learn from happiness research?'. Journal of Economic Literature 60, pp. 402-435.

Frey, B.S. and A. Stutzer: 2005, 'Beyond outcomes: Measuring procedural utility'. Oxford Economic Papers 57, pp. 90-111.

Guiso, L., P. Sapienza and L. Zingales: 2006, 'Does culture effect economic outcomes?', NBER Working Paper No. 11999, Cambridge (Mass.).

Headey, B., R. Muffels and M. Wooden: 2004, 'Money doesn't buy happiness ..., or does it? A reconsideration based on the combined effects of wealth, income, and consumption', Institute for the Study of Labor, Bonn, Discussion Paper No. 1218.

Headey, B. and M. Wooden: 2004, 'The effects of wealth and income on subjective well-being and ill-being'. Economic Record 80, pp. S24-S33. 
Heston, A., R. Summers and B. Aten: 2002, Penn World Table Version 6.1, Center for International Comparisons at the University of Pennsylvania (CICUP), Philadelphia, October.

Inglehart, R. and H. Klingemann: 2000, 'Genes, culture, democracy, and happiness', in E. Diener and E.M. Suh (eds.), Culture and Subjective Well-Being (MIT Press, Cambridge/London), pp. 165-183.

International Labor Organization: 2006, ILO Labor Force Statistics, Geneva, April 2006.

International Monetary Fund: 2005, World Economic Outlook Database, Washington D.C., September 2005.

Jungeilges, J. and G. Kirchgässner: 2002, 'Economic welfare, civil liberty, and suicide: An empirical investigation'. Journal of Socio-Economics 31, pp. 215-231.

Karatnycky, A. (ed.): 2000, Freedom in the World. The Annual Survey of Political Rights \& Civil Liberties 1999-2000 (Freedom House, New York).

Kenny, Ch.: 1999, 'Does growth cause happiness, or does happiness cause growth?'. Kyklos 52, pp. 2-26.

Lane, R.E.: 1991, The Market Experience (Cambridge University Press, Cambridge).

Lazear, E.P.: 1999, 'Culture and language'. Journal of Political Economy 107, pp. 95-126.

Lijphart, A.: 1979, 'Religious vs. linguistic vs. class voting. the 'crucial experiment' of comparing Belgium, Canada, South Africa, and Switzerland'. American Political Science Review 73, pp. $442-458$.

Luttmer, E.F.P.: 2004, 'Neighbors as negatives: Relative earnings and well-being', National Bureau of Economic Research, NBER Working Papers, No. 10667.

Marshall, M.G. and K. Jaggers: 2003, 'Polity IV Project: Political regime characteristics and transitions, 1800-2002. The Polity IV dataset'. Retrieved from http://www.cidcm.umd.edu/ inscr/polity/.

McBride, M.: 2001, 'Relative-income effects on subjective well-being in the cross-section'. Journal of Economic Behaviour and Organisation 45, pp. 251-278.

Moller, V. and H. Dickow: 2002, 'The role of quality of life surveys in managing change in democratic transitions: The South African case'. Social Indicators Research 58, pp. 267-292.

Moulton, B.: 1990, 'An illustration of a pitfall in estimating the effects of aggregate variables on micro units'. The Review of Economics and Statistics 72, pp. 434-438.

Oswald, A.J.: 1997, 'Happiness and economic performance'. The Economic Journal 107, pp. 1815-1831.

Perotti, R.: 1996, 'Growth, income distribution, and democracy: what the data say'. Journal of Economic Growth 2, pp. 149-187.

Pommerehne, W.W.: 1978, 'Institutional approaches to public expenditure: empirical evidence from Swiss municipalities'. Journal of Public Economics 9, pp. 255-280.

Schyns, P.: 1998, 'Crossnational differences in happiness: economic and cultural factors explored'. Social Indicators Research 43, pp. 3-26.

Schyns, P.: 2002, 'Wealth of nations, individual income and life satisfaction in 42 countries: A multilevel approach'. Social Indicators Research 60, pp. 5-40.

Stutzer, A. and B.S. Frey: 2003, 'Institutions matter for procedural utility: An economic study of the impact of political participation possibilities', in R. Mudambi et al. (eds.), Economic Welfare, International Business and Global Institutional Change (Edward Elgar, Cheltenham), pp. 81-99.

Van Doorslaer, E. and C. Masseria: 2004, 'Income-related inequalities in the use of medical care in 21 OECD countries', OECD Health Working Papers, No. 14/2004.

Veenhoven, R.: 2000a, 'Freedom and happiness: a comparative study in forty-four nations in the early 1990s', in E. Diener and E.M. Suh (eds.), Culture and Subjective Well-Being (MIT Press, Cambridge/London), pp. 257-288.

Veenhoven, R.: 2000b, 'The four qualities of life: Ordering concepts and measures of good life'. Journal of Happiness Studies 1, pp. 1-39.

Veenhoven, R.: 2001, 'Are the Russians as unhappy as they say they are?'. Journal of Happiness Studies 2, pp. 111-136. 
FAA-HSG

University of St. Gallen

Guisanstrasse 92

9010 St. Gallen, Switzerland

E-mail: alfonso.sousa-poza@unisg.ch

LSE-STICERD

London School of Economics

London, United Kingdom

SIAW-HSG, CESifo and Leopoldina

University of St. Gallen

St. Gallen, Switzerland
D. Dorn

A. Sousa-Poza

J.A.V. Fischer

G. Kirchgässner 